\title{
Eosinophil count (EC) as a diagnostic and prognostic marker for infection in the internal medicine department setting
}

\author{
STAMATIS KARAKONSTANTIS ${ }^{1, ~}{ }^{*}$, NIKI GRYLLOU ${ }^{1}$, GEORGE PAPAZOGLOU ${ }^{2}$, CHARALAMPOS LYDAKIS \\ ${ }^{1}$ Internal Medicine Department, General Hospital of Heraklion "Venizeleio-Pananeio", \\ Leoforos Knossou, Heraklion, Greece, Postal code 71409 \\ ${ }^{2}$ Emergency Medicine Department, General Hospital of Heraklion "Venizeleio-Pananeio", \\ Leoforos Knossou, Heraklion, Greece, Postal code 71409
}

\begin{abstract}
Introduction. Eosinopenia has been previously investigated as a marker to differentiate infectious from non-infectious diagnoses and as a prognostic marker. Most previous studies were conducted in intensive care unit patients. Our study focuses on the value of eosinopenia in patients admitted to the Internal Medicine department.

Methods. We retrospectively analyzed 271 consecutive patients with infection and 31 patients presenting with fever or inflammatory syndrome and a non-infectious diagnosis. We evaluated and compared the following markers for differentiating infectious from non-infectious diagnoses: eosinophil count [EC], CRP, WBC and neutrophil-to-lymphocyte count ratio [NLCR]. We also evaluated the value of eosinopenia as a monitoring parameter in patients with infections.

Results. Eosinopenia at admission was found in $71 \%$ of patients with infection compared to $32 \%$ in the non-infection group. EC and NLCR were moderate markers for discriminating infection from non-infection, with an area under the receiver operating characteristic curve of 0.789 and 0.718 respectively. Significant eosinopenia $(\leq 10 / \mu \mathrm{L})$ had a high specificity $(90 \%)$ for diagnosing infections. High EC at admission $(>400 / \mu \mathrm{L})$ was rare in the infection group (1.5\%), but not uncommon in the non-infection group $(25.8 \%)$. Persistent eosinopenia was noted in non-survivors, compared to the rapid normalization of EC in survivors.

Conclusions. Among patients presenting with fever and/or high inflammatory markers a low EC is supportive of infection, while a high EC may suggest non-infectious diagnoses. The persistence/ resolution of eosinopenia may be a useful monitoring parameter to predict response to therapy.
\end{abstract}

Key words: diagnosis, eosinophils, infection, internal medicine, prognosis.

\section{INTRODUCTION}

Eosinopenia of acute infection is considered to be the result of rapid sequestration of circulating eosinophils at the site of infection, mediated by chemotactic substances released during acute inflammation $[1,2]$. Other possible mechanisms include: acute stress mediated by adrenal glucocorticoids and epinephrine, suppression of egress of eosinophils from bone marrow and suppression of eosinophil production [1, 3-6].

Several studies have investigated eosinopenia as a diagnostic marker of infection. Gil et al. [7] showed that, among patients with CRP $>2 \mathrm{mg} / \mathrm{dL}$, eosinopenia $(<40 / \mu \mathrm{L})$ at admission to an internal medicine department had a high specificity and positive predictive value for infection. Then, Abidi et al. [8] found eosinopenia $(<50 / \mu \mathrm{L})$ at admission to the intensive care unit (ICU) to be a good marker of sepsis. However, subsequent studies in the ICU setting failed to reproduce these results [9-12].
More recently, profound eosinopenia $(<10 / \mu \mathrm{L})$ was found to be a very specific marker of sepsis in patients presenting to the Emergency Department [13]. Conversely, eosinophilia is rare in sepsis and its presence suggests alternative diagnoses $[14,15]$.

Eosinopenia has also been addressed as a prognostic marker of mortality in severe infection [14, 16-19]. Abidi et al. [16] found that eosinopenia < $40 / \mu \mathrm{L}$ at admission to the ICU and during the first 7 days is independently associated with mortality. Similarly, Terradas et al. [17] found that sustained eosinopenia $(<45 / \mu \mathrm{L})$ in patients with bacteremia was an independent risk factor for mortality, while in survivors' eosinophil counts tend to return to normal levels within 2-3 days. More recently monitoring the eosinophil count has been suggested as a marker of efficacy of antibiotic therapy [20-22].

Similarly to eosinopenia, there is also a rising interest in the neutrophil to lymphocyte count ratio as a diagnostic and prognostic marker $[17,19$, 23-26]. 
The main aim of this study was to assess the value of eosinophil count $[E C]$ as a marker to discriminate between infection and non-infection in the setting of an internal medicine department, and to compare it to $\mathrm{C}$-reactive protein [CRP], white blood cell count [WBC] and neutrophil to lymphocyte count ratio [NLCR]. We also assessed the value of $\mathrm{EC}$ as a monitoring parameter in patients with infection, by comparing survivors to nonsurvivors.

\section{MATERIALS AND METHODS}

\section{Study design}

Data were collected retrospectively from the electronic database of medical records of patients admitted to the Internal Medicine Department of a secondary-care community hospital in Greece, serving an area of 250000 inhabitants. Two groups of patients were retrospectively analyzed: (1) patients with a final diagnosis of infection and (2) patients with initial presentation of fever/inflammatory syndrome and with a final non-infection diagnosis (non-infection group). All consecutive medical admissions from September 2015 to August 2016 were evaluated for the inclusion/exclusion criteria described below. For the non-infection group, because of the small number of relevant cases, we extended the enrolment period from January 2014 (beginning of our electronic record) to August 2016. The study has been approved by the hospital's Ethics Committee.

\section{Inclusion criteria}

Regarding the infection group, patients were included if any of the following was satisfied: 1) a pathogen was isolated from a possible clinical focus or blood cultures (cases thought to represent contamination were excluded), 2) infection was documented with an imaging technique (e.g. intraabdominal abscess, pneumonia, osteomyelitis), 3) previously described definitions were satisfied (e.g. lower respiratory tract infections as defined by Woodhead et al. [27], Tokyo diagnostic criteria for acute cholangitis [28], modified Duke criteria for infective endocarditis [29], spontaneous bacterial peritonitis as defined by EASL guidelines [30]), 4) obvious clinical infection (e.g. cellulitis/erysipelas), 5) positive urinalysis (pyuria/positive nitrite test) in a patient with suspected urinary tract infection (dysuria symptoms, kidney pain, positive Giordano sign) and positive urine culture (unless the patient was already on antibiotics at the time of the culture) and no alternative diagnosis, 6) non-survivors presenting with circulatory shock, and high fever $\left(\geq 39^{\circ} \mathrm{C}\right)$ or high inflammatory markers (WBC > 20000 or CRP $>20 \mathrm{mg} / \mathrm{dL}$ ), and no alternative explanation, 7) positive lumbar puncture in patients with suspected CNS infection, 8) elderly patients with fever or high CRP/WBC and new lower respiratory tract findings (productive cough, dyspnea, hypoxemia) without a more likely alternative diagnosis (e.g. decompensated heart failure of non-infectious etiology).

Regarding the non-infection group, we selected patients presenting with fever $\left(\geq 38^{\circ} \mathrm{C}\right)$ or high inflammatory markers (WBC $>12000 / \mu \mathrm{L}$ or CRP $>$ $5 \mathrm{mg} / \mathrm{dL}$ ), with unclear diagnosis at presentation (including infectious causes in the initial differential diagnosis), and for whom a non-infectious cause was determined. Patients with a clearly non-infectious diagnosis (e.g. anemia, acute kidney injury, exacerbation of an already diagnosed rheumatologic disease, drug poisoning etc.) were excluded. To reduce selection bias, eligible patients were determined before accessing the patient's eosinophil counts (the electronic database we used to find our cases do not include eosinophil counts).

\section{Exclusion criteria}

We excluded the following patients: 1) use of corticosteroids before presentation, 2) active hematologic malignancy and 3) patients with suspected infection but not satisfying the criteria described above.

\section{Complete blood count analysis}

For blood counts the Cell-Dyn 3700 hematology analyzer was used. Eosinopenia was defined as $<50 / \mu \mathrm{L}$ in accordance with previous studies $[8,10]$ although various cut-off values have been described.

\section{Statistical analysis}

Statistical analysis was conducted with SPSS (IBM SPSS Statistics for Windows, Version 25.0. Armonk, NY: IBM Corp.). To study the diagnostic accuracy of EC, as well as CRP, WBC and NLCR, at admission for discriminating between infection and non-infection we plotted the receiver operating characteristic $[\mathrm{ROC}]$ curve and calculated the area under the curve [AUC], as well as the sensitivity [Sn], specificity [Sp] and positive and negative likelihood ratios [LR+ and LR-] for selected cut-off values. For between group comparisons we used 
non-parametric tests (Mann-Whitney U and KruskallWallis) because of the non-normal distribution of the data. Non-normal data are described with the median and the interquartile range $[\mathrm{IQR}]\left(1^{\text {st }}\right.$ to $3^{\text {rd }}$ quartile).

To test if EC is an independent predictor of the diagnostic category (infection versus noninfection) we used binary logistic regression. The other variables considered in this analysis were WBC, NLCR, CRP, age and sex. Only variables with $p$ values $<0.25$ in bivariate analyses were selected for the multivariate analysis. CRP had a value $>0.25$ but was still included in the model because of known clinical relevance.

\section{RESULTS}

\section{Characteristics of the study population}

Our database included 2771 patients from January 2014 to September 2016 (1145 patients from September 2015 to August 2016). Overall, $\mathrm{n}=384$ patients had a recorded diagnosis of infection. Of those, $n=25$ were excluded due to corticosteroid use before presentation, $n=3$ were excluded due to a prior diagnosis of chronic lymphocytic leukemia and $n=85$ were excluded because the diagnosis of infection could not be confirmed according to the pre-defined criteria and based on the available information (see methods). Among patients with a non-infection diagnosis fulfilling our criteria $n=4$ were excluded due to corticosteroid use. The final sample consisted of 271 patients in the infection group and 31 patients in the non-infection group. The duration of the symptoms that led the patients to the hospital was longer in the non-infection compared to the infection group (median of 7 days, IQR 2-22 versus median of 2 days, IQR $1-3, \mathrm{p}<0.001$ ), however this information was not reliably recorded and was available only for a portion of the patients $(24 / 31$ and 211/271 respectively). The characteristics of the study population are summarized in Table 1.

\section{Eosinopenia as a marker of infection}

Table 2 summarizes a comparison of EC, WBC, NLCR, CRP at admission between the infection and non-infection groups. EC at admission was significantly lower in the infection group (Figure 1) (median values: 20 vs. 140, $\mathrm{p}<0.001$ ). This difference remained statistically significant even after excluding the non-survivors (same median values, $\mathrm{p}<0.001$ ).
Comparing the ROC curves (Figure 2) and AUCs of EC, WBC, NLCR and CRP, we found that CRP (AUC 0.469, 95\% CI 0.376-0.562) and WBC (AUC 0.534, 95\% CI 0.426-0.643) were the least useful in distinguishing infection from noninfection in the population of our study. Eosinopenia (AUC 0.789, 95\% CI 0.707-0.872, p < 0.0005) and a high NLCR (AUC 0.718, 95\% CI 0.629-0.807, $\mathrm{p}<0.0005$ ) had a moderate diagnostic value. The results were similar even after excluding the nonsurvivors. At lower cut-off values eosinopenia was more accurate at "ruling-in" infection, at the cost of significantly reduced sensitivity, while at higher cut-off values EC may be useful to rule out infection (Table 3).

Combining the eosinophil count with a high NLCR may improve the specificity of the test at the cost of lower sensitivity (Table 3 ). However, the results regarding this combination are statistically non-significant (fisher's exact test) because of the very small number of patients in the non-infection group. In the multivariate binary logistic regression (including EC, NLCR and CRP as predictor variables) only EC was a significant predictor of infection (p value $<0.001$ ). EC retained its statistical significance even after adding to the model the duration of the main symptom before presentation.

\section{Eosinopenia as a monitoring parameter}

All non-survivors except one had eosinopenia $(<50 / \mu \mathrm{L})$ at presentation. The single patient without eosinopenia at presentation, a patient with advanced lung cancer, developed eosinopenia during hospitalization. Non-survivors as a group had significantly lower EC at admission (median EC $10 / \mathrm{uL}$ versus $20 / \mu \mathrm{L}$, Mann-Whitney $\mathrm{U}$ test $\mathrm{p}$ value $<$ 0.001). Furthermore, ECs tended to rise quickly in survivors while persistent eosinopenia was noted in non-survivors (Figure 3).

To further assess the utility of eosinopenia as a predictor of mortality we analyzed the ROC curves of eosinophil count at different days for discriminating survivors and non-survivors. The AUC was: 0.693 (95\% CI $0.608-0.778)$ on day 1 , 0.655 (95\% CI $0.559-0.750)$ at day 2, $0.755(95 \%$ CI $0.664-0.847)$ on day 3, 0.741 (95\% CI 0.623 $0.859)$ at day $4,0.776(95 \%$ CI $0.665-0.886)$ at day 5 . At later time points the number of non-survivors available for analysis was too small. At a cut-off of $<$ $50 / \mu \mathrm{L}$ EC yielded a sensitivity of $96.67 \%$, specificity $34.48 \%$, LR +1.47 and LR -0.096 for predicting mortality. 


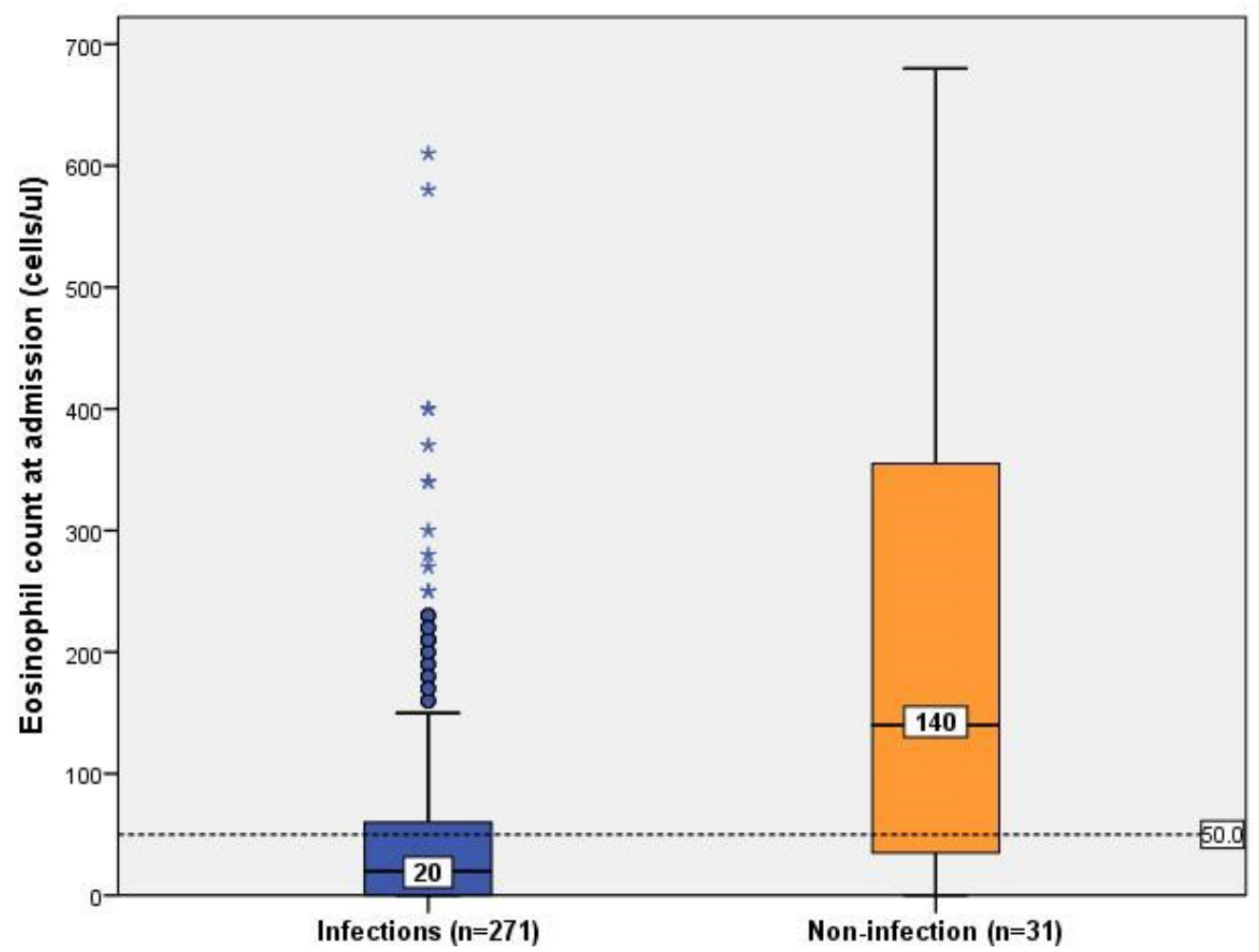

Figure 1. Comparison of eosinophil count $[\mathrm{EC}]$ at admission between infection and non-infection. SPSS boxplots (see methods section). The dotted line represents the cut-off for eosinopenia, i.e. $<50$ cells $/ \mu \mathrm{L}$. For illustration purposes the y-axis was resized to a max value of 700, resulting in 2 extreme values of the infection group $(920 / \mu \mathrm{L}$ and $1050 / \mathrm{uL})$ and one outlier in the non-infection group $(1080 / \mu \mathrm{L})$ not being shown in the chart.

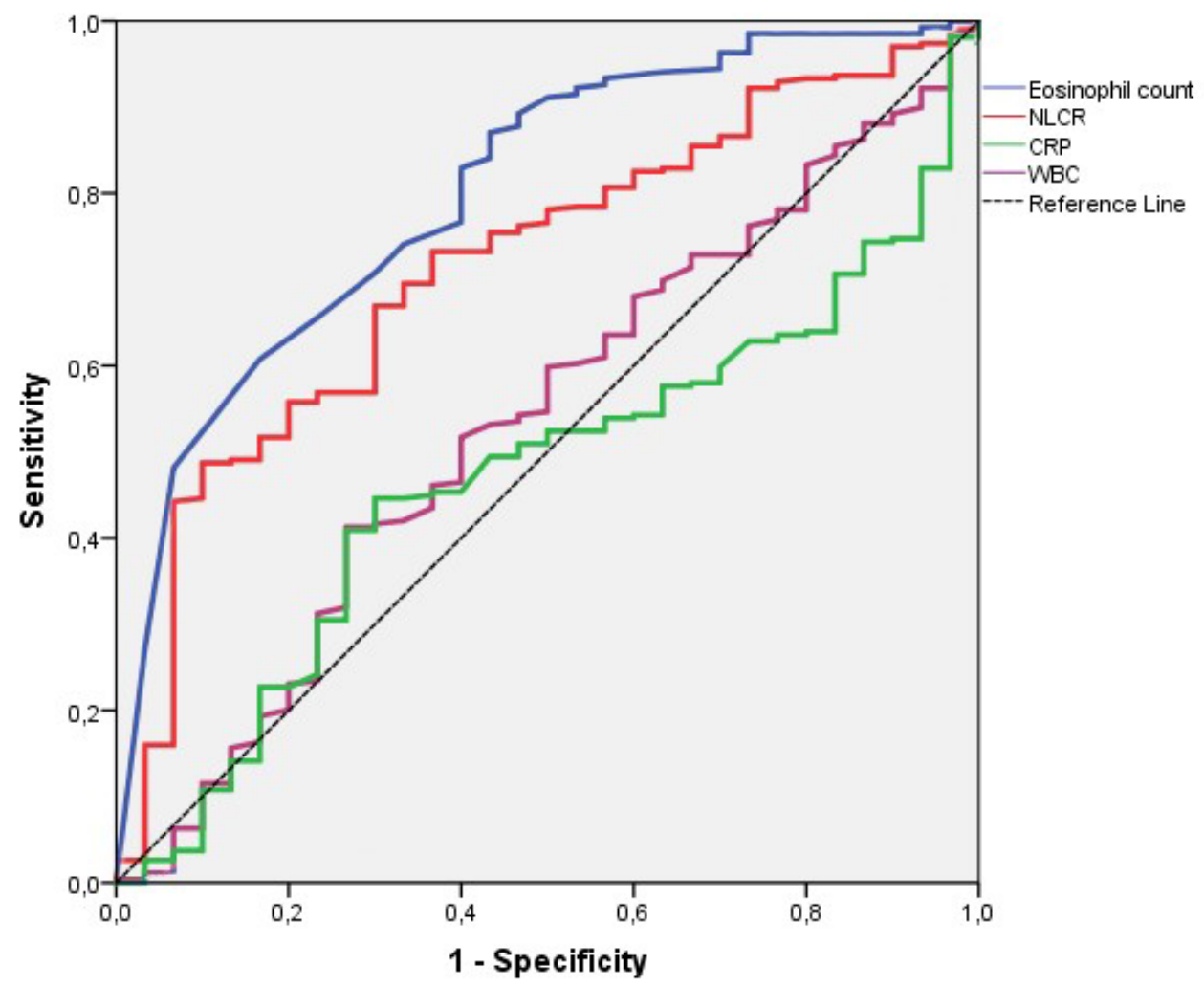

Figure 2. Receiver operating characteristic curves of eosinophil count, WBC, NLCR (neutrophil to lymphocyte count ratio) and CRP for the diagnosis of infection $v s$. non-infection. 
Table 1

Characteristics of the study population

\begin{tabular}{|c|c|c|c|c|}
\hline \multirow{2}{*}{ Diagnosis } & \multirow{2}{*}{ Number of patients } & \multicolumn{2}{|c|}{ Sex } & \multirow{2}{*}{$\begin{array}{c}\text { Age } \\
\text { (median/IQR) }\end{array}$} \\
\hline & & M & $\mathbf{F}$ & \\
\hline Infection & 271 & 142 & 129 & $78 / 62-86$ \\
\hline RTI & 115 & 63 & 52 & $79 / 64-87$ \\
\hline UTI & 94 & 44 & 50 & $75 / 58-83$ \\
\hline IAI & 30 & 15 & 15 & $81 / 67-86$ \\
\hline STI & 6 & 5 & 1 & $71 / 61-79$ \\
\hline Other $^{\mathrm{a}}$ & 18 & 11 & 5 & $76 / 50-81$ \\
\hline Unknown site (septic shock) $^{b}$ & 8 & 4 & 6 & $84 / 69-86$ \\
\hline Non-survivors & 30 & 14 & 16 & $83 / 75-87$ \\
\hline Non-infection $^{c}$ & 31 & 18 & 13 & $76 / 68-82$ \\
\hline
\end{tabular}

Abbreviations: IAI = intraabdominal infections (includes patients with intraabdominal abscess, cholangitis, spontaneous bacterial peritonitis and diverticulitis), IQR = interquartile range (first to third quartile), RTI = respiratory tract infection, $\mathrm{STI}=$ soft tissue infection (cellulitis), $\mathrm{UTI}=$ urinary tract infection

${ }^{a}$ Other $=$ osteomyelitis $(n=6)$, central nervous system infection $(n=3)$, spondylodiscitis $(n=1)$, epididymo-orchitis

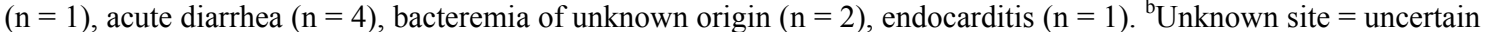
site of infection: 8 patients in the non-survivors' subgroup presenting with septic shock which however died before the site of infection could be identified. ${ }^{\mathrm{C}}$ Non-infecion: malignancy $(\mathrm{n}=15)$ (hepatocellular carcinoma $\mathrm{n}=4$, liver metastases $n=2$, prostate cancer with bone metastases $n=3$, pancreatic cancer with liver metastases $n=1$, pancreatic cancer with pulmonary embolism $n=1$, brain malignancy $n=1$, lymphoma $n=1$, gallbladder cancer $n=1$, esophageal cancer $n=1)$, autoimmune diseases $(n=12)$ (giant cell arteritis $n=4$, other systemic vasculitis $n=3$, undifferentiated arthritis $n=4$, polymyalgia rheumatica $n=1$ ), hyper-thyroidism/subacute thyroiditis $n=2$, drug-induced fever $n=1$, sterile pyuria $\mathrm{n}=1$.

Table 2

Comparison of EC, WBC, NLCR and CRP at admission between the infection and non-infection groups and between survivors and non-survivors

\begin{tabular}{|c|c|c|c|c|c|}
\hline & \multicolumn{3}{|c|}{ Infection group $(n=271)$} & \multirow[b]{2}{*}{$\begin{array}{l}\text { Non-infection } \\
\text { group }(n=31)\end{array}$} & \multirow[b]{2}{*}{$\begin{array}{l}\text { p value (infection } \\
\text { vs. non-infection) }\end{array}$} \\
\hline & All & $\begin{array}{c}\text { Survivors } \\
\mathrm{n}=\mathbf{2 4 1}\end{array}$ & $\begin{array}{c}\text { Non-survivors } \\
\mathbf{n}=\mathbf{3 0}\end{array}$ & & \\
\hline \multicolumn{6}{|c|}{$\mathrm{EC}($ cells $/ \mu \mathrm{L})$} \\
\hline Median & 20 & 20 & 10 & 140 & \multirow{2}{*}{ MWU p<0.001 } \\
\hline IQR & $0-60$ & $5-70$ & $0-12.5$ & $30-420$ & \\
\hline \multicolumn{6}{|c|}{ WBC $\left(10^{9} / \mathrm{L}\right)$} \\
\hline Median & 14 & 14 & 14 & 12.9 & \multirow[b]{2}{*}{ MWU p $=0.537$} \\
\hline IQR & $10-18$ & $10-18$ & $11-20$ & $10-17$ & \\
\hline \multicolumn{6}{|l|}{ NLCR } \\
\hline Median & 8.1 & 7.9 & 7.9 & 4.7 & \multirow{2}{*}{ MWU $\mathrm{P}=<0.001$} \\
\hline IQR & $5.3-16.6$ & $5-16$ & $6.1-23$ & $2.7-7.2$ & \\
\hline \multicolumn{6}{|c|}{ CRP(mg/L) } \\
\hline Median & 11.6 & 11.6 & 12 & 11.2 & \multirow{2}{*}{ MWU $p=0.572$} \\
\hline IQR & $4-18$ & $4-19$ & $3.4-17$ & $8-16.5$ & \\
\hline
\end{tabular}

$\mathrm{CRP}=\mathrm{C}$-reactive protein, $\mathrm{EC}=$ eosinophil count, $\mathrm{IQR}=$ interquartile range (first to third quartile). $\mathrm{MWU}=\mathrm{Mann}-$ Whitney $\mathrm{U}$ test, $\mathrm{NLCR}=$ neutrophil to lymphocyte count ratio, $\mathrm{WBC}=$ white blood cell count.

Table 3

Diagnostic characteristics of eosinophil count (EC), NLCR and the combination of EC and NLCR as markers of infection at different cut-off values

\begin{tabular}{|c|c|c|c|c|c|c|c|c|c|}
\hline Cut-off value & Sn & Sp & LR+ & LR- & Cut-off values & Sn & Sp & LR+ & LR- \\
\hline $\mathrm{EC}=0$ & $27 \%$ & $96.8 \%$ & 8.5 & 0.8 & $\mathrm{EC}=0+\mathrm{NLCR}>7$ & $19 \%$ & $100 \%$ & NA & 0.8 \\
\hline $\mathrm{EC} \leq 10$ & $48 \%$ & $90 \%$ & 5 & 0.6 & $\mathrm{EC} \leq 10+\mathrm{NLCR}>7$ & $32 \%$ & $96.7 \%$ & 9.5 & 0.7 \\
\hline $\mathrm{EC}<40$ & $71 \%$ & $68 \%$ & 2.2 & 0.4 & $\mathrm{EC}<40+\mathrm{NLCR}>9$ & $33 \%$ & $96.6 \%$ & 10.2 & 0.5 \\
\hline $\mathrm{EC} \leq 110$ & $87 \%$ & $55 \%$ & 1.9 & 0.2 & NCI D>10 & $410 \%$ & $0 ? 20$ & 60 & 0, \\
\hline $\mathrm{EC} \leq 200$ & $93.4 \%$ & $42 \%$ & 1.6 & 0.16 & NLCR $>9$ & $46 \%$ & $90 \%$ & 4.6 & 0.6 \\
\hline \multirow{2}{*}{$\mathrm{EC}<500$} & \multirow{2}{*}{$98.5 \%$} & \multirow{2}{*}{$10 \%$} & \multirow{2}{*}{1.1} & \multirow{2}{*}{0.15} & NLCR $>8$ & $51 \%$ & $83 \%$ & 3.1 & 0.6 \\
\hline & & & & & NLCR $>7$ & $57 \%$ & $70 \%$ & 1.9 & 0.6 \\
\hline
\end{tabular}

EC: eosinophil count, NLCR: neutrophil to lymphocyte count ratio. Sn: sensitivity, Sp: specificity, LR+: positive likelihood ratio, LR-: negative likelihood ratio.

Left table: Diagnostic characteristics of EC alone at different cut-off values.

Right upper table: Diagnostic characteristics of the combination of eosinopenia with NLCR. Discrepant results between EC and NLCR were treated as negative (e.g. positive test: $\mathrm{EC} \leq 10+\mathrm{NLCR}>7$, negative test: either EC $>10$ or NLCR $\leq 7$ ).

Right lower table: Diagnostic characteristics of NLCR alone. 


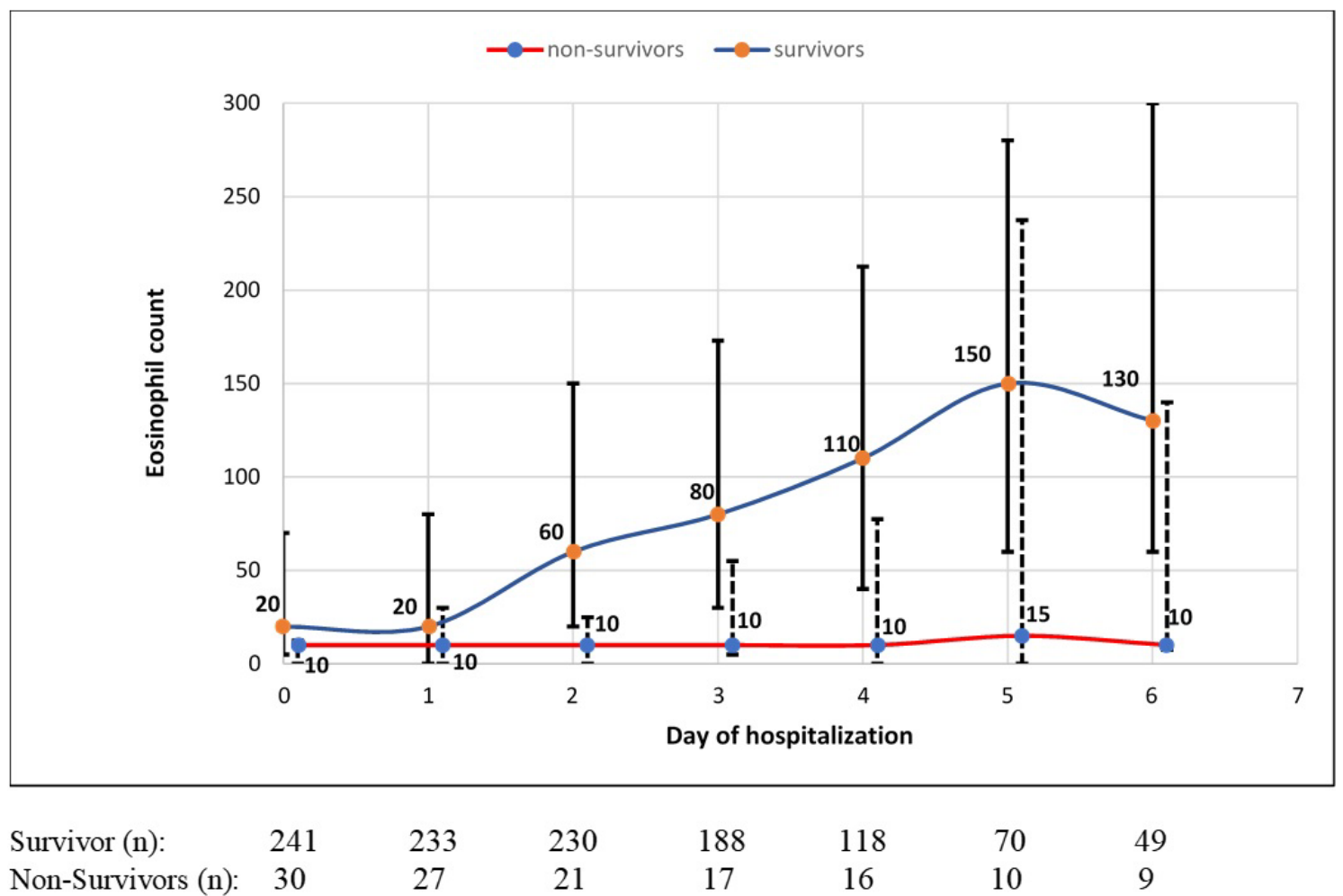

Figure 3. Eosinophil counts [EC] during hospitalization in survivors (blue) and non-survivors (red). The numbers in the graph correspond to the median EC on each day (top values = survivors, bottom values = non-survivors). The numbers below the graph correspond to the number of survivors and non-survivors available for analysis on each day. The solid lines represent the interquartile range $\left(1^{\text {st }}\right.$ to $3^{\text {rd }}$ quartile) of EC on each day in survivors, while the dashed lines represent the interquartile range of $\mathrm{EC}$ on each day in non-survivors. Mann-Whitney $\mathrm{U}$ test $\mathrm{p}$ values: day $0-<0.001$, day 1-0.008, day 2-<0.001, day 3-0.001, day 4- $<0.001$, day 5- 0.047 , day 6-0.03).

\section{Eosinophilia - a marker of non-infection?}

Only 4 of $271(1.5 \%)$ patients in the infection group had an $\mathrm{EC}>400 / \mu \mathrm{L}$ at admission, versus 8 of $31(25.8 \%)$ patients in the non-infection group. The higher the EC the higher was the likelihood for a non-infection diagnosis (Table 3).

\section{DISCUSSION}

\section{Summary of our findings}

We found that EC and NLCR may be useful markers for discriminating between infection and non-infection, although NLCR was not a statistically significant predictor in the multivariate analysis. Eosinopenia at low cut-off values $(\leq 10 / \mu \mathrm{L})$ yielded a high specificity (but low sensitivity) for the diagnosis of infection, while higher EC (especially > $400 / \mu \mathrm{L}$ ) usually suggest alternative non-infectious diagnoses. Regarding the prognostic value of eosinopenia, we showed that it has a very high sensitivity for predicting mortality but it was nonspecific. Of interest is the persistence of eosinopenia during hospitalization in the non-survivors' sub- group compared to the survivors' subgroup, with the latter showing a rapid normalization of EC within days.

\section{EC as a diagnostic marker}

Eosinopenia may be part of the acute stress response and has been described in a variety of severe acute non-infectious conditions (such as acute pancreatitis, severe bleeding or stroke) [19] which might explain the limited diagnostic value of eosinopenia in some of the studies conducted in ICUs [9-12]. On the contrary, patients with noninfectious inflammatory conditions, but chronic or subacute course, may be less likely to present with eosinopenia. In such settings the diagnostic value of eosinopenia may be higher $[7,31]$. For example, eosinopenia has been found to be a useful marker of infection among patients with fever of unknown origin lasting $>3$ weeks [31]. Our study's noninfection group focused on more acutely ill patients presenting with fever and/or high inflammatory markers. An alternative explanation for the difference of EC between infection and non-infection is that other inflammatory/immune mechanisms in noninfectious disease may drive $\mathrm{EC}$ to higher values. 
The absence of eosinopenia and more specifically eosinophilia may be a clue for the presence of non-infectious diagnoses (either as the main diagnosis or as a secondary diagnosis in a patient with infection). For example, in a study conducted in the tropical northern Australia (an area with a higher baseline occurrence of eosinophilia), eosinophilia was rare in patients hospitalized for infection (which is in agreement with our study where only 4 patients in the infection group presented with EC $>400 / \mu \mathrm{L}, 2$ of which had a known preexisting condition associated with eosinophilia) [14].

Several factors may explain the discordance among different studies regarding the diagnostic value of eosinopenia [19]. The small study samples, the differences in the study populations (different inclusion criteria and different settings: e.g. medical ICU, surgical ICU, internal medicine department, emergency department) and the variable composition of the non-infection group in different studies are important factors to consider when comparing these studies [19]. In contrast to most prior studies, for the non-infection group we selected patients presenting with fever and/or high inflammatory markers, with unclear diagnosis at presentation, and avoided including patients with apparent noninfectious diagnoses (which would probably overestimate the diagnostic value of eosinopenia [19]). This might also explain the low diagnostic value of CRP in our study, but makes our findings more relevant in terms of answering the question of whether EC can be a useful marker for discriminating infection from non-infection in patients who truly pose a diagnostic dilemma.

\section{EC as a monitoring parameter}

Similar to previous results $[14,16-18]$, we found a sustained eosinopenic response in nonsurvivors, while the median eosinophil count in survivors tended to quickly rise to normal levels within days. The value of eosinophil count in predicting response to antibiotic therapy was recently reported [20]. However, significant overlap of EC was noted between survivors and non-survivors in our study and persistent eosinopenia for several days was not uncommon in survivors (e.g. 77 of 188 patients in the infection group were eosinopenic at day 4, 44 of 118 were eosinopenic at day 5, and 23 of 70 were eosinopenic at day 6). The initiation of corticosteroids, a cause of eosinopenia, during hospitalization was not recorded in our study due to the retrospective design of the study.
Corticosteroid use may explain the persistence of eosinopenia in some of the survivors.

\section{Strengths and limitations of our study}

As already discussed the main strength of our study is that for the non-infection group we selected a more clinically relevant sample of patients, i.e., patients with uncertain diagnosis at presentation and presenting with fever and/or high inflammatory markers. Furthermore, our study was conducted in the internal medicine department setting, in contrast to most prior studies which were conducted in ICU patients.

However, our study has several limitations including the small study sample (especially the non-infection group) and most importantly the retrospective design. For example, other useful parameters like the presence of SIRS (systemic inflammatory response syndrome) criteria and corticosteroid use during hospitalization could not be evaluated accurately due to lack of some of the relevant data. Furthermore, eligible patients were selected based on the information available from our electronic database and many patients were excluded because they did not satisfy the criteria for inclusion to the infection group based on the available information. Moreover, in order to include a sufficient number of patients a longer eligibility period was used for patients in the noninfection group. This might have introduced some bias, e.g. if diagnostic and/or treatment methods changed before versus after August 2015. Nevertheless, we repeated the same analyses (except the multivariate analysis due to the small number of patients) only including patients from September 2015 to August 2016 in the non-infection group $(\mathrm{n}=16)$ and the results were very similar. Finally, given the retrospective design it was difficult to confirm with certainty whether deaths in nonsurvivors were all attributable to the underlying infection.

\section{CONCLUSION}

In conclusion, we found that eosinopenia and NLCR may be useful diagnostic markers for infection, and that the presence of high EC at admission should raise the suspicion for alternative non-infectious diagnoses. As a prognostic marker, eosinopenia at admission is a sensitive marker but with very low specificity for predicting mortality. Of interest is the persistence of eosinopenia in non- 
survivors compared to the rapid rise of EC in survivors. Prospective studies are needed to assess the value of EC in guiding clinical decision making. The trend of EC during hospital stay (persistence/ resolution of eosinopenia) could be used as a marker of prognosis and response to therapy.

Conflict of interest disclosure: The authors declare that there are not conflicts of interest

Introducere. Eozinopenia a fost evualată intensiv ca marker de diferențiere pentru infecții şi pentru prognosticul pacienților. Majoritatea studiilor anterioare s-au desfăşurat în cadrul secțiilor de terapie intensivă. Studiul nostru se concentrează pe evaluarea eozinopeniei la pacienții internați în Secția de Medicină Internă.

Materiale şi metode. Au fost analizați retrospectiv 271 de pacienți consecutivi cu infecție şi 31 de pacienți care s-au prezentat cu febră sau sindrom inflamator fără infecție. Au fost comparate între cele două grupuri mai multe variabile, numărul de eozinofile (EC), nivelul proteinei $C$ reactive $(P C R)$, numărul total de leucocite (WBC) şi raportul neutrofile/limfocite (NLR). Eozinopenia a fost evaluată pentru monitorizarea pacienților cu infecție.

Rezultate. $71 \%$ dintre pacienții cu infecție aveau eozinopenie la internare comparativ cu $32 \%$ din grupul non-infecție. EC şi NLCR au discriminat mediu infecția de non-infecție cu arii de sub curbă de 0.789 respectiv 0.718. Eozinopenia semnificativă $(\leq 10 / \mu L)$ a avut o înaltă specificitate (90\%) pentru diagnosticul infectiei. Numărul crescut de eozinofile (>400/ul) a fost rar întâlnit în grupul cu infecție (1.5\%), dar nu a fost neobişnuit in grupul non-infecție (25.8\%). Eozinopenia persistentă a fost observată la non-supraviețuitori comparativ cu normalizarea EC la supraviețuitori.

Concluzii. Eozinopenia este un marker ce sugerează infecția la pacienții cu febră şi/sau markeri inflamatorii pe când valori mai mari ale EC pot sugera un diagnostic non-infecțios. Persistența eozinopeniei ar putea fi un biomarker folositor pentru predicția răspunsului la terapie.

Correspondence to: Stamatis Karakonstantis, MD, MRes, Internal Medicine Department,

General Hospital of Heraklion "Venizeleio-Pananeio",Leoforos Knossou, Heraklion, Greece,

Postal code 71409; Phone number: +30 6940100298; ORCID ID: orcid.org/0000-0002-2643-3184

E-mail: stamatiskarakonstantis@gmail.com

\section{REFERENCES}

1. BASS D.A. Behavior of eosinophil leukocytes in acute inflammation. II. Eosinophil dynamics during acute inflammation. J Clin Invest. 1975;56(4):870-9.

2. BASS D.A., GONWA T.A., SZEJDA P., COUSART M.S., DECHATELET L.R., MCCALL C.E. Eosinopenia of acute infection: Production of eosinopenia by chemotactic factors of acute inflammation. J Clin Invest. 1980;65(6):1265-71.

3. DREYFUSS F., FELDMAN S. Eosinopenia induced by emotional stress. Acta Med Scand. 1952;144(2):107-13.

4. IVES M., DACK G.M. Alarm reaction and normal blood picture in Macaca mulatta. J Lab Clin Med. 1956;47(5):723-9.

5. BEST W.R., MUEHRCKE R.C., KARK R.M. Studies on adrenocortical eosinopenia: a clinical and statistical evaluation of four-hour eosinophil response test. J Clin Invest. 1952;31(7):733-42.

6. HILLS A.G., FORSHAM P.H., FINCH C.A. Changes in circulating leukocytes induced by the administration of pituitary adrenocorticotrophic hormone in man. Blood. 1948;3(7):755-68.

7. GIL H., MAGY N., MAUNY F., DUPOND J.L. [Value of eosinopenia in inflammatory disorders: an "old" marker revisited]. Rev Med Interne. 2003;24(7):431-5.

8. ABIDI K., KHOUDRI I., BELAYACHI J., MADANI N., ZEKRAOUI A., ZEGGWAGH A.A., et al. Eosinopenia is a reliable marker of sepsis on admission to medical intensive care units. Crit Care. 2008;12(2):R59.

9. SMITHSON A., PERELLO R., NICOLAS J.M. Is eosinopenia a reliable marker of sepsis? Crit Care. 2009;13(3):409.

10. SHAABAN H., DANIEL S., SISON R., SLIM J., PEREZ G. Eosinopenia: Is it a good marker of sepsis in comparison to procalcitonin and C-reactive protein levels for patients admitted to a critical care unit in an urban hospital? J Crit Care. 2010;25(4):570-5.

11. GARNACHO-MONTERO J., HUICI-MORENO M.J., GUTIERREZ-PIZARRAYA A., LOPEZ I., MARQUEZ-VACARO J.A., MACHER H., et al. Prognostic and diagnostic value of eosinopenia, C-reactive protein, procalcitonin, and circulating cell-free DNA in critically ill patients admitted with suspicion of sepsis. Crit Care. 2014;18(3):R116. 
12. ANAND D., RAY S., BHARGAVA S., SRIVASTAVA L.M., GARG A., GAFOOR I., et al. Exploration of eosinopenia as a diagnostic parameter to differentiate sepsis from systemic inflammatory response syndrome: Results from an observational study. Indian J Crit Care Med. 2016;20(5):285-90.

13. LAVOIGNET C.E., LE BORGNE P., SLIMANI H., FORATO M., KAM C., KAUFFMANN P., et al. [Relevance of eosinopenia as marker of sepsis in the Emergency Department]. Rev Med Interne. 2016;37(11):730-34.

14. PITMAN M.C., ANSTEY N.M., DAVIS J.S. Eosinophils in severe sepsis in northern Australia: do the usual rules apply in the tropics? Crit Care Med. 2013;41(10):e286-8.

15. MITRE E. Eosinophilia: a diagnostic clue for nonbacterial diseases in patients with systemic inflammatory response syndrome. Crit Care Med. 2013;41(10):2464-5.

16. ABIDI K., BELAYACHI J., DERRAS Y., KHAYARI M.E., DENDANE T., MADANI N., et al. Eosinopenia, an early marker of increased mortality in critically ill medical patients. Intensive Care Med. 2011;37(7):1136-42.

17. TERRADAS R., GRAU S., BLANCH J., RIU M., SABALLS P., CASTELLS X., et al. Eosinophil count and neutrophillymphocyte count ratio as prognostic markers in patients with bacteremia: a retrospective cohort study. PLoS One. 2012;7(8):e42860.

18. MERINO C.A., MARTINEZ F.T., CARDEMIL F., RODRIGUEZ J.R. Absolute eosinophils count as a marker of mortality in patients with severe sepsis and septic shock in an intensive care unit. J Crit Care. 2012;27(4):394-9.

19. KARAKONSTANTIS S., KALEMAKI D., TZAGKARAKIS E., LYDAKIS C. Pitfalls in studies of eosinopenia and neutrophil-to-lymphocyte count ratio. Infect Dis. 2018;50(3):163-74.

20. DAVIDO B., MAKHLOUFI S., MATT M., CALIN R., SENARD O., PERRONNE C., et al. Changes in eosinophil count during bacterial infection: revisiting an old marker to assess the efficacy of antimicrobial therapy. Int J Infect Dis. 2017;61:62-66.

21. KARAKONSTANTIS S., KALEMAKI D. Correspondence regarding "Changes in eosinophil count during bacterial infection: revisiting an old marker to assess the efficacy of antimicrobial therapy”. Int J Infect Dis. 2018;66(144.

22. DAVIDO B., MOUSSIEGT A., DE TRUCHIS P., SALOMON J., DINH A., DAVIDO G. Interest in the monitoring of eosinophil count as a marker of the response to antimicrobial therapy: In response to Karakonstantis and Dimitra. Int J Infect Dis. 2018;66:145-46.

23. NAESS A., NILSSEN S.S., MO R., EIDE G.E., SJURSEN H. Role of neutrophil to lymphocyte and monocyte to lymphocyte ratios in the diagnosis of bacterial infection in patients with fever. Infection. 2017;45(3):299-307.

24. NAESS A., MO R., NILSSEN S.S., EIDE G.E., SJURSEN H. Infections in patients hospitalized for fever as related to duration and other predictors at admittance. Infection. 2014;42(3):485-92.

25. KARAKONSTANTIS S., KALEMAKI D. Correspondence to "Role of neutrophil to lymphocyte and monocyte to lymphocyte ratios in the diagnosis of bacterial infection in patients with fever". Infection. 2017;10.1007/s15010-017-1069-1

26. VELISSARIS D., PANTZARIS N.D., BOUNTOURIS P., GOGOS C. Correlation between neutrophil-to-lymphocyte ratio and severity scores in septic patients upon hospital admission. A series of 50 patients. Rom J Intern Med. 2018;56(3):153-57.

27. WOODHEAD M., BLASI F., EWIG S., GARAU J., HUCHON G., IEVEN M., et al. Guidelines for the management of adult lower respiratory tract infections--full version. Clin Microbiol Infect. 2011;17 Suppl 6:E1-59.

28. KIRIYAMA S., TAKADA T., STRASBERG S.M., SOLOMKIN J.S., MAYUMI T., PITT H.A., et al. TG13 guidelines for diagnosis and severity grading of acute cholangitis (with videos). J Hepatobiliary Pancreat Sci. 2013;20(1):24-34.

29. LI J.S., SEXTON D.J., MICK N., NETTLES R., FOWLER V.G., JR., RYAN T., et al. Proposed modifications to the Duke criteria for the diagnosis of infective endocarditis. Clin Infect Dis. 2000;30(4):633-8.

30. EUROPEAN ASSOCIATION FOR THE STUDY OF THE L. EASL clinical practice guidelines on the management of ascites, spontaneous bacterial peritonitis, and hepatorenal syndrome in cirrhosis. J Hepatol. 2010;53(3):397-417.

31. EFSTATHIOU S.P., PEFANIS A.V., TSIAKOU A.G., SKEVA, II, TSIOULOS D.I., ACHIMASTOS A.D., et al. Fever of unknown origin: discrimination between infectious and non-infectious causes. Eur J Intern Med. 2010;21(2):137-43.

Received November 9, 2018 